\title{
Urs Steiner Brandt \\ Klimaeksperter og lægmænd. \\ Hvad betyder forskelle i risikoopfattelse for klimapolitikken?
}

\begin{abstract}
Klimaændringer opfattes af klimaeksperter som et alvorligt globalt miljøproblem, der nødvendiggør massiv indgriben. Den folkelige opbakning synes dog ikke at reflektere denne bekymring. Spørgsmålet er, hvorfor der er denne forskel i risikoopfattelsen. Uenigheden mellem eksperter og lægmænd er vigtig at forstå, da den kan have alvorlige konsekvenser for effektiviteten af den førte klimapolitik. Kombinationen af økonomisk beslutningsteori og adfærdspsykologi kan give et bud på, hvorfor ikke-eksperter har en anden risikovurdering end eksperter. Hvis politikere, af vælgerhensyn, i det mindste delvist baserer klimapolitikken på ikkeeksperters vurdering, betyder det, at der er en stor risiko for en fejlslagen klimapolitik. En ændret og bedre kommunikation af klimaproblemets risikoprofil kunne imidlertid harmonisere klimaeksperter og befolkningens risikoopfattelse og dermed fremme en effektiv klimapolitisk indsats.
\end{abstract}

COP15 klimatopmødet i København i december 2009 var af mange udråbt som "vor tids vigtigste møde". Hoved formålet var at udforme en international aftale om begrænsning af de forventede fremtidige klimaændringer og skadesvirkningerne heraf. Forhandlingsklimaet fulgte vejret uden for Forum: det blev gradvist koldere og kulminerede $\mathrm{i}$ en isnende atmosfære både uden for og inden for forhandlingslokalerne. Den fortsatte vinterkulde i Nord-og Vesteuropa blev ikke kun et symbol på nedkølede forventninger, men havde også konkrete effekter. I en overskrift i Mandag Morgen, Norge, marts 2010 stod at "en kold vinter får skylden for at klimasagen mister støtte hos befolkningen".

Forhandlingsparterne ved COP 15 mødet blev dog enige om en principerklæring, der specificerede klimaforhandlingernes langtidsmålsætning om, at den forventede globale gennemsnitstemperatur i dette århundrede ikke bør stige mere end 2 grader. Aftalen Copenhagen Accord indebar også, at landene frivilligt kunne indberette deres forventede udledningsreduktioner indtil februar 2010. Copenhagen Accord er ikke en juridisk bindende aftale, og de forventede reduktioner, som landene indgav i 2010, bygger derfor alene på politiske løfter. Beregninger fra det internationale energiagentur (IEA, 2010) viser imidlertid, at den aftalte målsætning ikke sikres med de reduktioner $i$ udslip af drivhus- 
gasser, landende har indberettet. Desuden er denne beregning baseret på, at landene gør, som de har lovet, hvilket der ikke er nogen garanti for.

Ifølge eksperter vil klimaændringerne blandt andet føre til vandstandsstigninger, ørkendannelser, mere og voldsommere ekstremt vejr og reduktion i biodiversitet. Desuden mener det internationale klimapanel IPCC (2007), at hovedårsagen til den tiltagende globale opvarmning og deraf følgende klimaændringer) er den menneskeskabte udledning af drivhusgasser (især kuldioxid $\left(\mathrm{CO}_{2}\right)$ og metan $\left(\mathrm{CH}_{4}\right)$ ), forårsaget af afbrænding af fossile brændstoffer og skovrydning. Især fossile brændstoffer fungerer som væsentlige produktionsfaktorer i både produktion og forbruget og er dermed essentielle for de fleste landes økonomier. En opgørelse fra World Meteorological Organization viser imidlertid, at koncentrationen af drivhusgasser sætter ny rekord selv efter finanskrisen, hvilket viser, at end ikke den økonomiske afmatning har kunnet stoppe den markante stigning af drivhusgasserne i atmosfæren (WHO, 2010).

En effektiv reduktion af udslip af drivhusgasser kræver en indsats på alle samfundsniveauer. Intentionen i den såkaldte Copenhagen Accord fra 2009 om at begrænse den globale temperaturstigning til 2 grader vil ifølge Stern (2007) formodentlig kræve en reduktion på ikke mindre end 60-80 pct. af den nuværende globale udledning af drivhusgasser. For at opnå dette kræves massive investeringer og implementeringer af ny, renere teknologi i områder som energiproduktion, forbrug og transport, hvilket ligger langt over fx den målsætning, som den Europæiske Union har fastsat. På den anden side ligger det på linje med Klimakommissionens (2010) anbefalinger om, at elektricitet skal blive omdrejningspunktet for energisystemet. 40-70 pct. af energiforbruget skal dxkkes af el mod 20 pct. i dag, og havvindmøller bliver centrale. Endvidere skal huse opvarmes med eldrevne varmepumper, og transportsektoren omlrgges til el og biobrændsler.

Talrige undersøgelser viser imidlertid, at klimatruslen bliver taget med betydelig større skepsis blandt befolkningen (ikke-eksperter) end blandt klimaeksperter. Denne skepsis relaterer sig både til, hvorvidt klimaændringerne er reelle, dvs. om hvorvidt den globale temperatur er stigende, og især om denne stigning helt eller delvist er menneskeskabt. Denne såkaldte perceptionskløft kan forklares ved hjælp af økonomiske og psykologiske modeller. Samtidig indicerer modellerne, hvorfor klimapolitiske skræmmekampagner ikke bidrager til at gøre befolkningen mere bekymrede over truslen fra global opvarmning.

Denne artikel søger svar på følgende overordnede spørgsmål: Hvorfor er der forskel på klimaeksperters og den almene befolknings opfattelse af risikoen ved at udlede drivhusgasser i samme eller eventuelt øget omfang som hidtil? Hvad betyder denne forskel for kommunikationen af klimaproblematikken og der- 
med for mulighederne for at føre en effektiv klimapolitik? Artiklen tager afsæt i en kortlægning af befolkningens holdninger til risikoen ved klimaændringer og deres tillid til ekspertopfattelser. Dernæst analyseres perceptionskløften ud fra økonomisk beslutningsteori under risiko og adfærdspsykologi. Efterfølgende ses på konsekvenserne heraf for en effektiv klimapolitik. Endelig afsluttes der med en diskussion af, hvordan forskellige kommunikationsmetoder, der tager hensyn til klimaproblemets karakter og befolkningens mentale reaktion på dette kompleks, vil kunne bidrage til en større sammenhæng mellem den ekspertfunderede klimatrussel og befolkningens opfattelse heraf.

\section{Befolkningens holdninger til klimaforandringer}

En effektiv nedsættelse af udledningen af drivhusgasser kræver helt grundlæggende befolkningens deltagelse og engagement. Ifølge Leiserowitz et al. (2010) Spence og Pidgeon (2009) og især McNaughten og Jacbos (1997) er der tre hovedårsager til, at den offentlige opfattelse af klimatruslen er altafgørende i forhold til mulighederne for at gennemføre klimapolitikker: Ændringer i vaner og livsstil, direkte/indirekte politisk støtte og modstand/støtte til konkrete klima- og energitiltag. Mens de sidste to punkter er åbenlyse, er det væsentligt at bemærke, at individuel deltagelse er instrumental både i forhold til forbrugsvaner/efterspørgsel og som signal til industrien/producenter om udvikling af mindre forurenende teknologi/produkter. McNaughten og Jacobs (1997) nævner blandt andet følgende måder, hvorpå befolkningens valg er instrumentelt: leve grønt, genbruge, energibesparelse, brug af offentlig transport/cykel og køb af lokale produkter. Deres hovedpointe er, at sådanne ændringer kun er mulige, hvis befolkningen føler ejerskab til projektet, dvs. er i stand til at identificere og erkende klimaproblemet som værende reelt og væsentligt og har forståelse for, at de nævnte ændringer har betydning for at afhjælpe problemet.

Da det folkelige engagement er essentielt for at få implementeret effektive klimapolitikker, er det naturligt, at der er foretaget en hel række undersøgelser med det formål at afdække befolkningernes holdning til spørgsmål vedrørende klimaændringerne. Det gælder for det første, hvorvidt befolkningen erkender klimaforandringerne, for det andet om de opfatter sådanne forandringer som menneskeskabte, og om der på dette område er forskel mellem klimaeksperternes og befolkningens opfattelse. For det tredje er det et spørgsmål, om klimaforandringer opfattes som en anderledes eventuelt mindre trussel end andre trusler.

Den grønne tænketank Concito har siden februar 2010 kvartalsvist offentliggjort et klimabarometer, som viser, at et stort flertal af danskerne (omkring 70 pct.) er enige eller helt enige i spørgsmålet: "Er den gennemsnitlige tempe- 
ratur på jorden stigende", hvorimod 3-6 pct. er uenige. (Concito, 2010a, b og c). Samtidig viser undersøgelsen, at 55 pct. i februar 2010 mente, at klimaændringerne er menneskeskabte imod kun 10 pct., der mener, at det ikke er tilfæl$\operatorname{det}$ (Concito, 2010a). I de to nyeste undersøgelser (juni og oktober) er andelen, der mener, at klimaændringer er menneskeskabte, imidlertid steget til 60 pct. (Concito, 2010b og c). Til samme spørgsmål viser en norsk undersøgelse fra 2009 , at 70 pct. er enige eller delvist enige, mens 16 pct. var enten uenige eller delvist uenige (Mandag Morgen, 2010). Generelt viser internationale meningsmålinger, at lidt over halvdelen af de adspurgte opfatter temperaturstigningerne (eller klimaændringerne) som helt eller delvist menneskeskabte som $\mathrm{fx}$ en stor EU-undersøgelse, hvor 31 pct. er enige, men 57 pct. uenige i spørgsmålet, om udledning af $\mathrm{CO}_{2}$ og andre drivhusgasser kun har en marginal effekt på klimaændringer (EU, 2009). Globale undersøgelser viser imidlertid store nationale forskelle. På spørgsmålet om den stigende temperatur er resultatet af menneskelige aktivitet, viser Gallup-USA undersøgelsen, at Japan ligger i top med 91 pct. enige (Gallup-USA, 2009). I modsætning hertil ligger europæiske lande omkring 45-60 pct., og USA er på 49 pct. For USA's vedkommende, hvor spørgsmålet er stillet siden 2003, er dette det hidtil laveste (Gallup-USA, 2010).

På trods af denne alligevel relativt store enighed om, at klimaforandringer er menneskeskabte, er der en mere generel opfattelse af, at klimatruslen er blevet overdrevet af klimaeksperter. Den norske undersøgelse fra 2009 viser, at 45 pct. af de adspurgte opfatter klimatruslen som overdrevet, og 25 pct. er blevet mere skeptiske i løbet af de sidste 1-2 år (Mandag Morgen, 2010). Over halvdelen af de adspurgte mener dog stadigvæk, at klimatruslen er alvorlig. EU-undersøgelsen fra 2009 viser samme tendens, idet 23 pct. mener, at alvoren af klimaændringerne har været overdrevet (EU, 2009).

To nylige hændelser har bidraget til at reducere tilliden til klimaeksperterne. Den ene er den såkaldte klimaskandale fra 2009 (også omtalt som climagate). Den betegner en hændelse, som fandt sted i november 2009. Forskere fra klimaforskningsinstituttet CRU i England blev i medierne beskyldt for at have manipuleret data eller overvejet at gøre dette for at fremhæve klimaeffekten. Den anden er næstformanden for FN's klimapanel IPCC, Jean-Pascal van Yperseles, erkendelse af, at forskerpanelet i sin omfattende statusrapport fra 2007 har brugt en udokumenteret og forkert oplysning om hastigheden af $\mathrm{Hi}$ malaya-gletsjernes afsmeltning, som følge af den globale opvarmning (Information, 2010). Konsekvensen heraf for tilliden til IPCC er målt i to amerikanske undersøgelser. Undersøgelsernes resultater er ikke fuldstændig enslydende, men tendenserne er de samme. Den ene undersøgelse viser, at ca. 20 pct. har 
hørt om og fulgt debatten om klimaskandalen. Af disse har 49 pct. fået mindre eller meget mindre tillid til klimavidenskabsfolk, og kun 6 pct. har fået mere tillid (Leiserowitz et al., 2010). Den anden undersøgelse viser, at kun ca. 10 pct. har hørt om og fulgt debatten om IPCC's fejl, hvoraf 54 pct. i varierende grad har mistet tillid til klimavidenskabsfolk, mens 13 pct. har fået mere tillid. Begge undersøgelser viser, at det er hos klimaskeptikerne, vi finder størst fald i tilliden. Endvidere er 46 pct. af dem, der har hørt om hændelserne, blevet mindre sikre på, om klimaændringer er reelle, mens 24 pct. er mere sikre herpå (Leiserowitz et al., 2010). Spørgsmålet om tillid til IPCC er også taget op i den norske undersøgelse, som viser, at efter offentliggørelsen af IPCC-fejlen har 39 pct. mindre tillid, og kun 1 pct. mere tillid til IPCC (Gallop-Norge, 2010).

Skepsis til klimaeksperter understreges af, at befolkningen oplever, at klimaeksperter er uenige om, at klimaændringerne er menneskeskabte. Anderegg et al. (2010) gennemgår fagtidsskrifterne for klimavidenskab og konkluderer, at der er en slående enighed blandt klimavidenskabsfolk om tesen angående den menneskeskabte klimaændring. Derimod er der blandt den amerikanske befolkning betydelig tvivl om både den menneskeskabte årsag til klimaændringerne og især den videnskabelige enighed om dette. En undersøgelse af Pew Research Center (2009) underbygger dette. I interviewundersøgelsen vises, at kun 56 pct. af befolkningen tror, at videnskaben generelt er enig i, at temperaturstigningerne er menneskeskabte.

Skepsis til klimaeksperter og skepsis omkring klimaforandringer som menneskeskabte kan forventes at have betydning for, hvordan befolkningen opfatter truslen ved klimaændringer relativt til andre væsentlige trusler. De tidligere omtalte undersøgelser af Concito viser, at til spørgsmålet om, hvad der bekymrer danskerne mest, topper klimaændringer $\mathbf{i}$ alle tre målinger (ca. 20 pct.). Terrorfrygten er markant faldende, mens arbejdsløshed, finanskrisen og indvandring/integration også skaber bekymring. EU-rapporten (2009) konkluderer, at klimaændringer opfattes som det næstværste problem af 62 pct. af europæere efter "sult og mangel på drikkevand" ( 68 pct.), men foran international terrorisme (53 pct.). Interessant er det, at denne undersøgelse bygger på tre spørgerunder med otte måneders mellemrum og viser store udsving. Således steg området "A major economic downturn" i februar 2009 over klimaændringer, rimeligvis pga. finanskrisen. Globalt set er der imidlertid stor spredning mellem, hvad forskellige landes befolkninger vurderer som den største trussel eller udfordring. En global interviewundersøgelse (Ipsos MORI poll, 2010) viser, at det i USA kun er 22 pct. af befolkningen, der ser klimaændring som en af de to eller tre største udfordringer, mens 62 pct. oplever terror som en af disse. I Kina er tallene omvendt. Her ser 67 pct. klimaxndring som en af de to 
eller tre største udfordringer, mens det kun er 17 pct., der oplever terror som en af de største trusler. Ingen af de omtalte undersøgelser vurderer klimaændringerne som en ekstraordinær trussel i forhold til andre internationale/globale trusler som terror, fattigdomsproblemer og finansiel krise.

Den overordnede konklusion er, at klimaændringer rangerer højt $\mathrm{i}$ folks bevidsthed. Færre mener dog, at klimaændringer er menneskeskabte (generelt mellem 45-70 pct.), og denne skepsis er ikke blevet mindre i de sidste år. Endelig er der en fejlagtig opfattelse af, at klimaeksperter er uenige om klimaproblemets årsag, og tilliden til klimaeksperters udsagn er følsom over for selv relativt små unøjagtigheder.

\section{Beslutninger under risiko}

Udgangspunktet i økonomisk beslutningsteori under risiko er en forventet nyttehypotese. Under risiko, dvs. en situation hvor mindst en handling kan føre til flere mulige udfald, skal en beslutningstager vælge den handling, der maksimerer den forventede nytte. Ifølge denne model er der kun en måde at træffe beslutninger på, nemlig at usikkerheden skal kvantificeres ved hjælp af sandsynligheder, og de forskellige konsekvenser skal beskrives i nyttetermer. Endelig skal man vælge den beslutning, som på baggrund af de beregnede sandsynligheder giver den største forventede nytte. Denne rationelle beslutningsproces er dermed en normativ model.

Lindley (1985) accepterer, at valg af handling afhænger af beslutningstagerens personlighed, men mener ikke, at en uemotionel, abstrakt og metodisk analyse af en matematiker er ubrugelig, for selv om der er en stærk menneskelig komponent involveret i processen, kan vi profitere af bevidste beregninger. Inden for adfærdspsykologien undersøges hjernens informationsforarbejdning. Dette kan overordnet set opdeles i to tankesæt. Det associative (emotionelt baserede og affektivt drevne) system og det analytiske/videnskabeligt baserede (kognitive) system.

Gennem det associative system opfattes verden holistisk, og virkeligheden afkodes i billeder, metaforer og narrativer. Oplevelserne bliver fortolket affektivt og via associationskæder. Konsekvensen er, at virkeligheden ikke prøves forstået, men forsøges fortolket, så det oplevede placeres i en velkendt og dermed genkendelig forståelsesramme. Systemet er medfødt, og dets måde at forarbejde sanseindtryk på er en grundlæggende menneskelig evne, som hverken kan læres eller slukkes. Systemet giver øjeblikkeligt følelsesmæssige og kropslige (viskorale) reaktioner og er derfor hurtig og transformerer de ugunstige aspekter af omgivelserne i følelser som frygt, angst, eller bekymring, som så påvirker beslutningerne. 
Det andet system er det analytiske system, som opererer ud fra logik, og er fornuftsorienteret og konsistent. Det analytiske system afkoder og forstår virkeligheden i abstrakte symboler, ord og tal. Systemet er langsomt og udskyder handlinger, da handlingerne skal retfærdiggøres ud fra logik, refleksion og evidens, og ud fra en bevidst vurdering af hændelserne. Det vil dermed udskyde handlinger, der udløses spontant af det associative system. Systemet er bevidst, skal tillæres og bliver her opfattet som den "videnskabelige" tilgang til at bearbejde information.

Den forventede nytte tager udgangspunkt i en reduktionistisk tilgang, hvor vi antages at anvende det logiske system til opdeling af problemer i overskuelige delelementer, lave en grundig analyse af elementerne, og til sidst skabe et samlet overblik. Idet forventet nytte-hypotesen bygger på anvendelse af det logisk/analytiske system, kan dette sidestilles med den måde, den videnskabelige tilgang arbejder på.

Der er fra flere fagområder blevet sat spørgsmålstegn ved, om det analytiske system giver en tilfredsstillende beskrivelse af måden, vi foretager beslutninger på. Kahneman og Tversky (1979) afprøvede i eksperimentelle rammer forventet nytte-hypotesen og konkluderede, at der forekom en systematisk afvigelse i forhold til, hvad forventet nytte-hypotesen havde forudsagt. Inden for adfærdspsykologien, som er udgangspunktet for opdeling i de to tankesystemer, viser forskning, at ikke-eksperter i høj grad benytter sig af det associative system, og at i tilfæelde, hvor de to systemer er i modstrid med hinanden, vil det associative dominere beslutningsprocessen (Weber, 2010).

Kahneman og Tversky (1979) udviklede prospektteorien, som er en deskriptiv model for personers beslutningstagning under risiko som konsekvens af eksperimentelt fastslåede systematiske afvigelser fra forventet nytte-hypotesen. Kahneman og Tversky drager disse overordnede konklusioner: Sandsynligheder er erstattet med beslutningsvægte, således at små sandsynligheder overvurderes, mens store sandsynligheder tilsvarende undervurderes. Derudover finder Kahneman og Tversky, at personer anvender en værdifunktion (i stedet for en nyttefunktion), som indeholder en framing-effekt, hvor personer evaluerer tab eller gevinster ud fra afvigelser fra et referencepunkt (typisk initialsituationen). Værdifunktionen er konkav i gevinster (medførende risikoaversion) og konveks for tab (risikosøger) og generelt stejlere for tab end for gevinster (tabsaversion). Dette implicerer, at man er villig til at tage en risiko for et stort tab for at forhindre et sikket tab (når begge alternativer giver samme forventede afkast), men ikke villig til at tage en chance for en stor gevinst, når muligheden for en mindre, men sikker gevinst er til stede. Konkret vil det betyde, at et sikkert udfald med $800 \mathrm{kr}$. vil blive foretrukket frem for et usikkert, hvor der er 50 
pct. chance for at tabe $4000 \mathrm{kr}$. og 50 pct. chance for at vinde $5000 \mathrm{kr}$., hvis status quo-punktet er initial indkomst jf. figur 1.

Figur 1: Et eksempel på en nyttefunktion ifølge prospektteorien

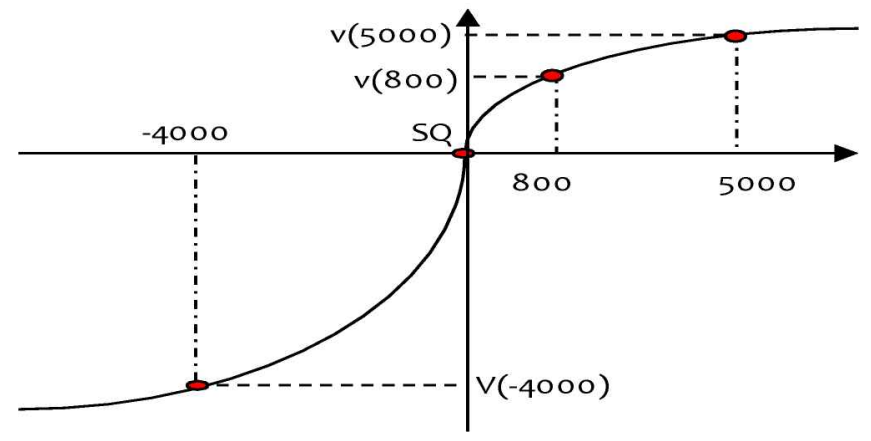

Prospektteorien giver en begyndende forståelse for, at vi i beslutningsprocesserne anvender heuristiks (tommelfingerregler), og at sandsynligheder er subjektive. Derimod mangler vi en forklaring på, hvordan vi danner de subjektive sandsynligheder, og hvordan denne proces relaterer sig til klimaændringer. Forklaringen herpå kan findes i den del af den adfærdspsykologiske litteratur og forskning, der har beskæftiget sig med beslutningsprocesser.

Som det fremgik af foregående afsnit, kan der observeres stor forskel i risikovurderingen af eksperter og ikke-eksperter vedrørende de menneskeskabte klimaændringer. Den generelle forskel mellem risikoopfattelsen af videnskabsfolk (eksperter) og "lægmand" er også beskrevet i Slovic and Weber (2002), der sammenholder en ekspertrangorden af forskellige typer risici med rangorden af ikke-specialister. Fx rangordnes risikoen ved atomkraft som nummer 20 (ud af 30) af eksperter, mens ikke-eksperter rangordner risikoen ved denne energiform højest. De forklarer denne forskel med, at mens eksperter lægger tekniske estimater til grund for deres vurdering, vurderer lægmænd på baggrund af andre typer risikokarakteristika. Forskellen mellem den oplevede risiko ved en trussel og den "virkelige" risiko, beskrevet fx ved hiælp af statistik, data eller modelberegninger, som essentielt dækker over forskellen mellem tryghed og sikkerhed, kalder Ropeik (2010) for perception gap (perceptionskløft). Den kan tolkes som forskellen mellem, hvordan en trussel opfattes i den offentlige mening og ekspertvurderinger.

Den adfærdspsykologiske forskning har udviklet det såkaldte psykometriske paradigme (Slovic et al., 1982), hvor det forsøges at kvantificere, hvilke karakteristika ved et problem der bestemmer risikoperceptionen ved dette problem, 
når vi anvender det associative system, dvs. bestemmer opfattelsen af alvoren af truslen og sandsynligheden, hvormed den vil ramme os. Den psykometriske forskning har identificeret en vifte af karakteristika, der påvirker vores risikoopfattelse. Der findes forskellige opgørelser af sådanne karakteristika, hvor en udgave er gengivet i tabel 1. Grundessensen er, at vores risikoopfattelse påvirkes af, om risikoen er potentielt katastrofal, ufrivillig, ukontrollerbar og særlig rædselsvækkende.

Tabel 1: Udvalgte faktorer, der påvirker vores risikoopfattelse

\begin{tabular}{ll}
\hline Faktorer & Forklaring \\
\hline Kontrol & $\begin{array}{l}\text { Jo mere kontrol man føler, man har over en situation, jo mindre } \\
\text { bange er man }\end{array}$ \\
Valg & $\begin{array}{l}\text { Jo mere risikoen er selvvalgt, jo mindre skræmmende tager den } \\
\text { sig ud }\end{array}$ \\
Vi accepterer det naturlige som mindre skræmmende end det \\
menneskeskabte
\end{tabular}

Kilde: Ropeik (2010).

Ud fra oplevelsen af disse faktorer kan den individuelle risikoopfattelse opgøres. Denne metode kan også forklare, hvorfor der er individuelle forskelle i risikoopfattelser, idet faktorerne er subjektivt oplevede (vurderede) ud fra en række personlige forhold. Opgørelsen kan så sammenholdes med det faktiske trusselsbillede for at vurdere, om den subjektivt oplevede trussel er over- eller undervurderet i forhold til den "objektive" trussel. Klimaændringer virker fjerne og abstrakte og fremstår i manges opfattelser ikke som en umiddelbar trussel, men som en langsom transition til et andet klima. Det er svært at sætte billeder på klimaændringer. Modsat $\mathrm{fx}$ terror, som opfattes nærværende, taler til følelserne, er rædselsvækkende og skaber associationer om død og ødelæggelse. Samtidig opfattes terror intentionel, og vi kan give den et ansigt, fx kendte terrorister eller hændelser (9-11), den er potentielt altid ny, og vi kan blive ramt af den overalt (se fx Lorenzoni et al. (2006), Lowe (2006) og Sunstein (2007)). 
Disse faktorer spiller sammen med det erfaringsgrundlag, vi besidder, om klimaændringerne. Erfaringer om klimaændringer relaterer sig oftest alene til ekstreme (klimaændringsrelaterede) hændelser. Undersøgelser viser, at vi tillægger tidsmæssigt nære oplevelser betydelig mere vægt end mere distante oplevelser. Ifølge Weber (2010) vil disse hændelser i gennemsnittet have en mindre indflydelse på beslutningsprocesserne end deres reelle sandsynlighed burde. Men det giver også et større individuelt og periodisk udsving i risikoopfattelsen. Fx kan to kolde vintre opfattes som et signal om, at klimaændringer ikke er reelle. Konsekvensen af disse karakteristika ved klimaændringerne er, at en befolknings samlede vurdering af klimatruslen er mindre, men samtidig mere fluktuerende end eksperternes vurdering.

Tabel 2: Risikoopfattelse på grundlag af truslens karakteristika

\begin{tabular}{cc}
\hline Klimaændring & Terror \\
\hline Distant & Nærværence \\
Tilvænning & Rædsel \\
Uden hensigt & Intentionel \\
Kronisk & Katastrofe \\
Abstrakt & Personificering \\
Velkendt & Ny \\
Ikke en umiddelbar trussel & En umiddelbar trussel \\
\hline
\end{tabular}

Denne folsomhed i befolkningens risikoopfattelse over for enkelthændelser vises i flere studier. Ifølge Franck (2008), viser amerikanske undersøgelser, at forsikringsgraden vokser dramatisk efter en ekstrem hændelse, men falder tilbage til det tidligere niveau i løbet af 5-10 år. Når den ekstreme hændelses tilgængelighed ( $i$ vores bevidsthed) svinder, og grundejerne vænner sig til den risiko, de står over for, falder forsikringsgraden og lader samfundene vare relativt ubeskyttet. Ifølge Franck (2008) vil beskyttelsesforanstaltninger kun ligge på et forhøjet niveau en kort periode. Et ikke uvæsentligt forhold, der har betydning for, hvor risikofyldt en potentiel trussel opfattes, er det personlige erfaringsgrundlag. Ifølge Whitmarch (2008) virker erfaringer som et filter, hvorigennem de mange risici, vi dagligt konfronteres med, evalueres og rangordnes. Nylige katastrofer (som kan relateres til en given trussel) eller stor mediedækning er med til at forvride risikoopfattelsen, hvilket fx var tilfældet med 9-11 (Keller et al., 2006). En helt ny undersøgelse af Spence et al. (2011) dokumenterer dette for klimaproblemet. I deres undersøgelse vises, at perceptionen af klimaænd ringer og villigheden til energibesparelser er positivet korre- 
leret med personligt erfarede oversvømmelser. På samme måde opfattes lokale risici mere betydningsfulde end distante (Hinchliffe, 1996).

Endelig besidder vi ifølge Weber (2010) en begrænset kognitiv kapacitet, og opmærksomhed er dermed en knap kognitiv ressource. Den kognitive begrænsning skaber en situation, hvor forskellige risikogenererende systemer indbyrdes danner positionelle eksternaliteter. Øget opmærksomhed mod én reducerer opmærksomhed mod de andre. Når denne observation kobles med antagelsen om, at forøget opmærksomhed medfører en højnelse af risikoopfattelsen af det pågældende system, er konklusionen, at konkurrerende risikoskabende systemer er indbyrdes negativt korrelerede. Dermed vil ikke-eksperters opfattelse af truslen ved menneskelig udledning af drivhusgasser også påvirkes af $f_{x}$ tilstedeværelsen af en finanskrise eller et forhøjet terrorberedskab.

Det foregående kan nu samles til en forklaring af perceptionskløften. Forklaring følger i figur 2, som anvendes som den konceptuelle model til at identificere "perceptionskløften" på klimaområdet. Udgangspunktet er tilstedeværelsen af reelle klimaændringer, som hovedsageligt er forårsaget af menneskeskabte udledninger af drivhusgasser. Klimaeksperterne beskrives ved hjælp af statistik, data og modelberegninger. Den måde, hvorpå videnskaben afkoder dette fænomen, vil vi kalde for ekspertvurderingerne. Disse beregninger og vurderinger er nedfældet i fx IPCC-rapporterne. Ifølge Weber (2010) baserer klimaforskerne deres vidensproduktion på den analytiske del af informationsbearbejdningen, fordi de er skolede i de nødvendige analytiske redskaber, har adgang til de relevante data, ofte har personlig erfaring med klimaændringerne og større tiltro til deres analytiske system og dataene. IPCC-rapporterne læses oftest ikke af ikke-eksperter og skal derfor formidles på anden vis via massemedier, dokumentarer eller undervisning. Dvs. de bliver i vid udstrækning allerede fortolket, inden de når befolkningen.

Essensen i figur 2 er, at vores vurdering af klimatruslen afhænger af mange opfattede faktorer. I princippet kan opskrives et udtryk for denne individuelle trusselsoplevelse som

$$
\rho_{1}(\text { trussel ved } \mathrm{K} Æ)=\mathrm{f}_{\mathrm{i}}\left(F 1_{\mathrm{i}}, F 2_{\mathrm{i}},,, F \mathrm{~N}_{\mathrm{k}}\right)
$$

Faktorerne $F 1_{i}, F 2_{i},, F_{k}$ angiver niveauer af de faktorer, der kunne tænkes at opvirke risikoopfattelsen. I figur 2 er medtaget den oplevede reelle trussel, naturlige udsving $\mathrm{i}$ klimaet, tilstedeværelsen og variation $\mathrm{i}$ opfattelsen af andre trusler, IPCC-rapporterne, og massemedieudlægningerne af klimakomplekset. Fodtegnet, $i$, angiver, at den funktionelle form er individuel, påvirket af faktorer beskrevet i tabel 2 og den tillid, individet har til kilderne til informa- 
Figur 2: Faktorer, hvorigennem den offentlige opfattelse af klimaændringer dannes

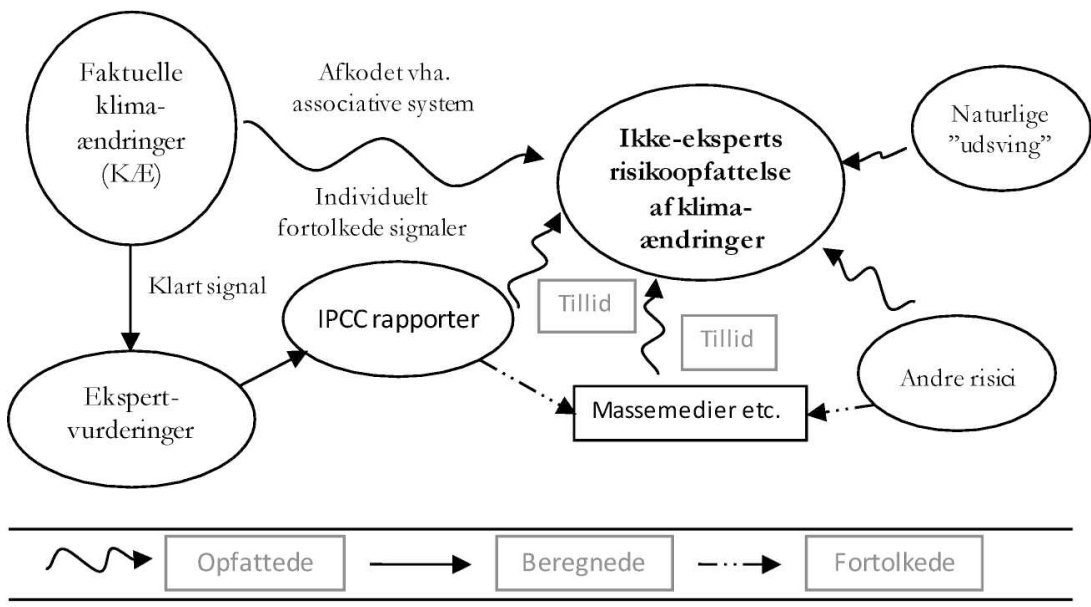

tion. Ifølge Weber (2010) har vi mest tillid til personer eller grupper, som vi deler værdinormer og/eller politisk overvisning med. Med denne gennemgang af både empirien og de teoretiske forklaringer af perceptionskløften er vi nu i stand til at analysere betydningen af befolkningens risikoopfattelse for klimapolitikken.

\section{Betydningen for klimapolitikken}

I det følgende anskueliggøres konsekvenserne af en klimapolitik, der (delvist) baserer sig på befolkningens volatile risikoopfattelse. For at inddrage befolkningens perception i beslutningsprocessen forestilles, at selvom politikere afstikker optimale klimapolitikker (KP) (både på kort og lang sigt), vil implementeringssuccesen være påvirket af befolkningens opfattelse af klimaændringernes (KÆ) reelle signifikans, som igen afhænger af de i figur 2 beskrevne baggrundsvariable, og/eller [1].

$K P^{1}=\alpha \cdot K P^{\text {videnskab }}$, hvor $\alpha=\alpha\left(f_{i}\right), \alpha>0$ på en noget kompleks måde skitseret i figur $2 . \alpha<1$ betyder, at politikken ikke implementeres tilstrækkeligt, mens $\alpha>1$ betyder, at politikken over-implementeres, dvs at der allokeres for mange af samfundets ressources til dette formål.

Klimapolitikker vil dermed kunne afvige fra det optimale, fordi et særkende for investeringer i energisystemer er den lange løbetid af investeringerne (Stern, 2007). Sådanne investeringer er ofte i høj grad sunk. Udbygning af kulfyrede kraftværker, opførelse af et a-kraftværk eller havvindmølleparker (som fx på Kriegers Flak) vil give en teknologisk og/eller økonomisk sti-afhængighed. Det 
vil enten være meget dyrt eller teknologisk komplekst at foretage relativt hurtige korrektioner i forhold til den valgte sti. Denne tendens forstærkes ved tilstedeværelsen af teknologisk lock-in. Acemoglu et al. (2010) analyserer tilstedeværelsen af stiafhængighed i retningen af teknologisk udvikling. Artiklen viser, at har en virksomhed først foretaget innovation i en mængde beskidt teknologi, vil den også finde det mere profitabelt at gøre det i nuværende periode og reagerer mindre på priseffekter ( $f_{x}$ skatter eller kvotemarker for at give et prissignal om innovation i ren teknologi). Konklusionen er, at denne teknologiske lock-in medfører teknologisk stiafhængighed, som komplicerer mulighederne for at rette op på en midlertidig ikke-optimal klimapolitik.

Mange teknologier inden for energisektoren indeholder ifølge Stern (2007) endvidere netværkseksternaliteter, hvilket er defineret ved, at værdien af et produkt for en forbruger forøges med antallet af personer, der har erhvervet sig det tilsvarende produkt. Et stort problem ved fx elbiler er netop netværkseksternaliteter, idet det først bliver lønsomt at købe elbiler, når så mange allerede har elbiler, at den nødvendige infrastruktur som support til elbiler bliver profitabel. Udbygningen af vejnettet giver også stiafhængighed, forstået på den måde, at det dermed bliver billigere og nemmere at anvende bilen, og dermed bliver det mere fordelagtigt at satse på privatbilisme med en selvforstærkende effekt til følge. På samme måde har udbygning og effektivisering af fx tognettet en selvforstærkende indvirkning på den samfundsmæssige gevinst af yderligere satsning på den kollektive trafik. Konklusionen er, at en midlertidig afvigelse fra den optimale klimapolitik resulterer i:

- Større omkostninger, når hurtige æendringer er nødvendige

- Teknologisk fastlåsning

- For $\alpha<1$ større sårbarhed

- For $\alpha>1$ overbeskyttelse

Antages det, at $\alpha$ i en langere periode undervurderes, vil der blive investeret for lidt i klimatiltag. En mulig konsekvens er afbildet i figur 3. I perioder med naturlige udsving og faldende gennemsnitstemperatur vil befolkningens oplevelse være, at global opvarmning ikke finder sted. Når begge temperaturkomponenter (menneskeskabte som naturlige) virker samme vej, og vi vil opleve en hurtig stigning i temperaturen, står vi meget sårbart tilbage. Da klimapolitikker tager tid at implementere, fx ved tilpasningerne, eller er ekstremt omkostningsfyldte, hvis de skal implementeres over meget kort tid, kan vi risikere, at beskyttelsesniveauet er lavt, idet investeringer i tilpasning er for små.

På samme måde vil politikker ikke på kort sigt kunne påvirke klimaændringer positivt. Det vil sige, at politikker baseret på perception, der påvirkes af 
Figur 3: Risikoen for fejlagtig klimapolitik baseret på subjektiv risikoopfattelse

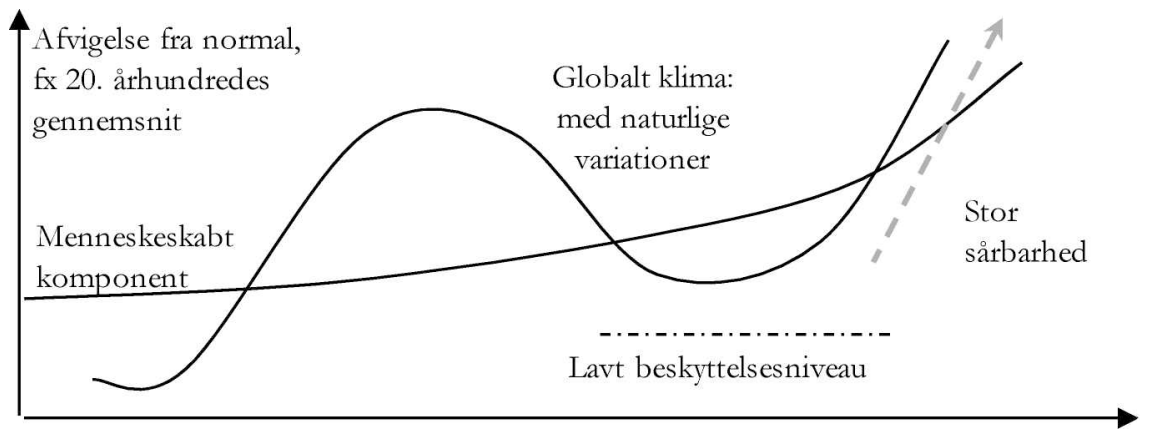

(ekstreme) vejrhændelser, vil medføre underudbud af klimapolitikker i perioder med en negativ naturlig påvirkning af temperaturen. Dette gør samfundet sårbart ved en efterfølgende positiv påvirkning af temperaturen.

Konklusionen er, at politikker baseret på befolkningens oplevelse af klimaændringer både er dyrere og samtidig ikke giver samme sikkerhed som politikker baseret på ekspertvurderinger. Opgaven må derfor være at reducere perceptionskløften, så der er bedre overensstemmelse mellem eksperters og ikke-eksperters opfattelse af risikoen.

\section{Risikokommunikation}

Ser vi tilbage på figur 2 ligger en væsentlig årsag til ikke-eksperters risikovurdering i den måde, hvorpå såvel klimaproblemet som ekspertopfattelsen heraf kommunikeres. Siden perceptionskløften kan afstedkomme uhensigtsmæssige politiske resultater, vil det være i samfundets interesse at formindske denne. Udgangspunktet for at overvinde perceptionskløften ligger i risikokommunikation. Risikokommunikation er ifølge WHO (2009) en interaktiv proces af udveksling af information og holdninger imellem dem, der vurderer risikoen (IPCC), risiko managers (politikere, virksomheder) og andre interesserede parter. Det er en proces, der skal skabe en gensidig forstålse mellem den, der regulerer, og den regulerede med det formål at afstemme interesser og mål. Men uanset hvilken part, der er tale om, vil det ofte være fristende at anvende en skræmmekampagne

En strategi for at forøge den offentlige bevidsthed om truslen ved klimaændringer er at indgyde frygt. Skræmmekampagner kan have en effekt. Fx udtaler Sundhedsstyrelsens forebyggelseschef, Else Smith, i Ugeskrift for lager, 29. april 2009, at internationale erfaringer viser, at de barske billeder har effekt, og at effekten ser ud til at være stærkest i netop de befolkningsgrupper, der ryger 
mest. Skræmmekampagner appellerer til angst eller frygt. Mekanismen er at stimulere følelsen af truslen, som målgruppen skal kunne føle, ved at forsøge at vække frygt med det formål at frempromokere forsigtighedsforanstaltninger og selv-beskyttende handlinger (O'Neill og Nicholson-Cole, 2009). Ifølge O'Neill og Nicholson-Cole kan erfaringer fra sundheds- og marketingsrelaterede discipliner dog ikke umiddelbart overføres til klimaændringsproblematikken. Den personlige erfaring og dermed identifikation med problemet mangler, da konsekvenserne af klimaændringer, som vi har set, ofte opfattes som upersonlige og distante. Erfaringer fra fx ikke-rygekampagner kan derfor ikke umiddelbart overføres til klimaændringerne, da det ikke er muligt at appellere til den enkelte persons frygt på dette område. Moser og Dilling (2004) konstaterer, at når et individ konfronteres med frygt, igangsætter det ønsket om kontrol af denne frygt. Da individet ikke kan forventes at kunne kontrollere klimaændringerne ved ændring i adfærd, er det nødsaget til at kontrollere den indre frygt, hvilket resulterer i benægtelse og apati. Derfor vil skræmmekampagner inden for klimaændringer på længere sigt nærmere have den modsatrettede effekt, end hvad formålet var.

Inden for marketing er vigtigheden af opmærksomhedsskabelse for længst erkendt inden for en gren af videnskaben, der kaldes attention economics. En veltilrettelagt kommunikationsstrategi til formidling af den potentielle risiko ved klimaændringer vil med fordel kunne benytte sig af viden fra denne del af litteraturen. Spørgsmålet bliver da, om information kan "frames" af de relevante beslutningstagere, så den opfattes tydeligere, reducere perceptionskløften, og sikre forudsætningerne for en effektiv implementering af klimapolitikker? Framing inden for samfundsvidenskaben angiver, at når vi forsøger at forklare en hændelse, afhænger forstålsen af hændelsen og dens årsag $\mathrm{i}$ den forståelsesramme, individet sætter hændelsen ind i.

Vender vi tilbage til prospektteorien, angiver den netop, at personer anvender en værdifunktion, der indeholder en framing-effekt således, at personer evaluerer tab eller gevinster ud fra afvigelser fra et referencepunkt, og samtidig lægger for lidt vægt på hændelser/udfald, der ikke er sikre i forhold til sikre udfald. Denne indsigt kan anvendes og er blevet anvendt på følgende måde. Ifølge Rothman og Salovey (1997) kan risikokommunikation (inden for sundhed, men også mere generelt) opdeles i enten en gevinstramme eller en tabsramme.

Hver af disse rammer kan yderligere opdeles ud fra, om fokus er på handlinger eller resultater, som illustreret $\mathrm{i}$ tabel $3 \mathrm{a}$. Eksempler på disser typer framing er givet $\mathrm{i}$ tabel $3 \mathrm{~b}$. Dette generelle skema kan anvendes til at frame budskaber, når dette sammenholdes med prospektteorien. Vi kan illustrere dette ved at ændre på status quo-punktet. Forestiller vi os, at der er et sikkert udfald, en 
tilpasning, der giver en gevinst på 800, mens en "ikke indgrebs"-politik enten giver et stort tab (-4000), hvis der bliver klimaændringer, eller en stor gevinst (+5000), hvis der ikke bliver klimaændringer. Begge udfald antages lige sandsynlige.

Tabel 3a: Framing-muligheder

\begin{tabular}{llcc}
\hline & & \multicolumn{2}{c}{ Resultat } \\
& & Ønskelig & Ikke ønskelig \\
\hline \multirow{2}{*}{ Handling } & Opnå & Gevinstramme (A) & Tabsramme (B) \\
& Ikke opnå & Tabsramme (C) & Gevinstramme (D) \\
\hline
\end{tabular}

Tabel 3b: Eksempel med reduktion af udslip af drivhusgasser

\begin{tabular}{lll}
\hline & Ønskelig & Ikke ønskelig \\
\hline Opnå & $\begin{array}{l}\text { Reduktion af udledning } \rightarrow \\
\text { fastholdelse af højt sikkerhedsniveau }\end{array}$ & $\begin{array}{l}\text { Fortsat udledning } \rightarrow \text { risikerer et } \\
\text { uacceptabelt lavt sikkerhedsniveau }\end{array}$ \\
$\begin{array}{l}\text { Ikke } \\
\text { opnå }\end{array}$ & $\begin{array}{l}\text { Fortsat udledning } \rightarrow \text { ikke fastholdelse } \\
\text { af højt sikkerhedsniveau }\end{array}$ & $\begin{array}{l}\text { Reduktion af udledning } \rightarrow \text { risikerer } \\
\text { ikke et uacceptabelt lavt sikkerheds- } \\
\text { niveau }\end{array}$ \\
\hline
\end{tabular}

Ønskes det, at tilpasning implementeres, vil det være ideelt at fokusere på tabet ved at gøre ingenting. Tages tabet som referencepunkt, så alternativerne fremstår som gevinster, vil det sikre udfald blive foretrukket, jf. figur 4 a. Hvis vi derimod ønsker den usikre politik implementeret, så kan fokuseringen på gevinst ved risikable udfald, hvor alternativerne fremstår som tab, afbildes som vist i figur $4 \mathrm{~b}$.

Figur 4a: Eksempel hvor fokusering på tab medfører, at det sikre udfald vurderes som bedst

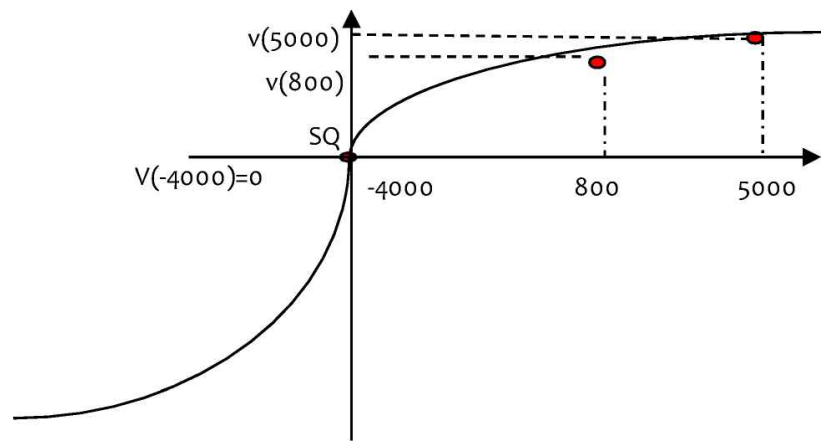


Figur 4b: Eksempel hvor fokusering på gevinst medfører, at det risikable udfald vurderes som bedst

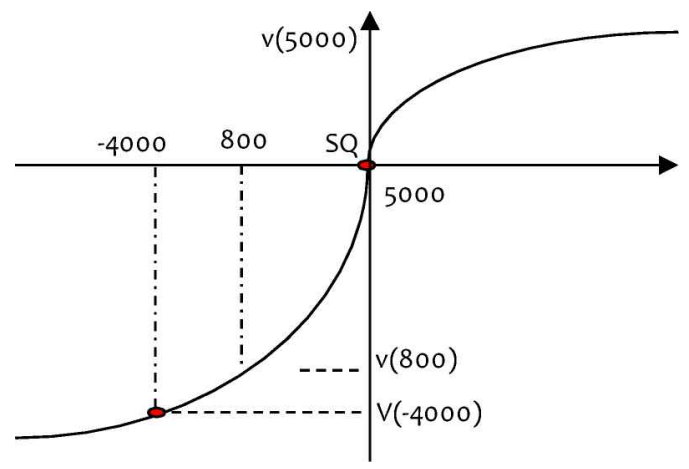

Moser og Dilling (2004) tager også udgangspunkt i prospektteorien og dens resultater om, hvordan vi opfatter gevinster og tab forskelligt. De angiver, at politikker, der har en høj succesrate, som $\mathrm{fx}$ tilpasningsinvesteringer, er bedst framet, hvis de fremhæver gevinsterne ved politikken (gevinstramme A, jf. tabel 3a) Årsagen hertil er, at vi ifølge prospektteorien ofte vælger det sikre resultat i forhold til det risikable, ved tilstedeværelsen af en mulig, men ikke sikker, større gevinst ( $\mathrm{fx}$ gevinsten ved ikke at gøre noget, hvis klimaændringer ikke opstår). Mindre sikre valg, (dvs. hvor succesraten er mindre), bør frames, så tabene fremhæves. Ud fra prospektteorien er vi villige til at risikere et stort tab for at forhindre et mindre, men sikkert tab. En risikofyldt politik kan være EU's enegang på klimaområdet for via lederskab at få andre store udledere som USA og Kina til at indgå i en effektiv klimaaftale. Denne politik bør frames som tabsramme B, jf. tabel 3a: Hvis EU ikke går enegang ved at foretage krævende reduktioner, vil vi miste muligheden for at nå en global aftale, og dette vil være en katastrofe for verden. Og dermed fortiet at det på ingen måde er sikkert, at EU's handlinger har nogen tilstrækkelig effekt på USA's eller Kinas klimapolitikker.

Vi må dog til ovenstående bemærke, at det ikke er sandsynliggjort, om det er de samfundsmæssige bedste politikker, der bliver implementeret, kun at beslutningstagerne ved hjælp af den rette framing kan forbedre mulighederne for at implementere de ønskede politikker. Det vil også være vigtigt at få beskrevet de muligheder, der findes for individuelle handlinger, for på den måde at højne identifikationen og det lokale engagement i klimaændringer og fjerne fokus fra betydning af enkelthændelser for vores opfattelser af klimaændringer. Et væsentligt formål med denne proces er dermed at gøre den regulerede part en del af processen og på den måde give fornemmelsen af ejerskab til projektet. 
Fra regeringens side kan der skabes incitamenter, så det er i forbrugernes egeninteresse at handle klimarigtigt, ved fx at give tilskud til "klimarigtig opførsel" eller pålægge afgifter på mindre gode klimaløsninger.

\section{Konklusion}

Hovedspørgsmålet var, hvilken betydning forskelle i risikoopfattelse havde for klimapolitikken. Her observerede vi som udgangspunk en forskel mellem eksperter og lægmænd på området. Klimaændringerne er et stort kompleks, som det er vanskeligt at danne sig et overblik over, hvis man ikke er ekspert og har en stor klimamodel til rådighed. I stedet baserer vi lægmænd (ikke-eksperterne) vores opfattelse af risikoen ved klimaændringer på den information, vi mere eller mindre tilfældigt støder på. De specielle karakteristika ved klimaændringer og de mekanismer, der ligger til grund for vores opmærksomhed og forarbejdning af information, resulterer generelt $i$, at vi undervurderer risikoen ved klimaændringerne. Den sædvanlige negative konklusion kan drages: Det er først, når vi modtager så stærke signaler fra det ændrede klima, at det opfattes som en reel trussel, at der kommer så meget fokus på problemet, at effektive klimapolitikker kan implementeres. Men på grund af strukturen i den globale opvarmning vil det $\mathrm{i}$ værste fald være for sent at stoppe problemet, fordi drivhusgasserne så allerede er akkumuleret i atmosfæren, uanset hvor meget vi så evner at reducere udslippene efterfølgende.

Eftersom politikere af vælgerhensyn ofte er villige til at basere klimapolitikken på lægmændenes vurdering, så øges risikoen for en fejlslagen klimapolitik. Klimaænd ringernes karakter nødvendiggør derfor, at befolkningen identificerer sig med problemet og engagerer sig i løsninger på problemet, men hvordan kan engagementet øges yderligere? Politikere som fx Al Gore og andre velmenende fortalere for effektive globale tiltag har for at modvirke klimaændringerne og den tiltagende globale opvarmning i en vis udstrekning anvendt elementer af skræmmekampagner. Dog viser logikken fra prospektteorien, at skræmmekampagner ikke er en farbar vej for at kommunikere truslen fra klimaændringerne til en bredere befolkningsgruppe. Framing er som udgangspunkt et perspektiv på en såkaldt intelligent kommunikationsstrategi. Identifikation og personligt engagement er dermed opnåelig, hvis man ikke prøver at skræmme befolkningen, men anvender en risikokommunikation, hvor de individuelle fordele ved personlige tiltag fremhæves, og mulighederne lægges frem. Dog mangler der erfaringer med langtidseffekterne af den type kommunikation. Framingtankegangen kan dog ogsả bruges til at fremhæve gevinstmuligheder ved konkrete tiltag. Fx at cykling er bedre end bil, ikke kun på grund af klima, men også for helbredet. Sparepærer er gode, fordi de skåner miljøet og sparer 
penge, osv. Der er dog heller ikke nogen indicier på, at sådanne framingstiltag vil have langtidseffekter på klimaområdet.

For klimaeksperterne vil en mulig strategi være at kommunikere den endnu herskende usikkerhed ud mere præcist. Der er faktisk ikke den store uenighed blandt klimaforskere om de væsentligste elementer i klimaproblematikken. Bedre kommunikation af klimaproblemets risikoprofil kunne fremover bidrage til en harmonisering af klimaeksperter og lægmænds risikoopfattelse og dermed bane vejen for en mere effektiv klimapolitik.

\section{Litteratur}

Acemoglu, Daron, Philippe Aghion, Leonardo Bursztyn and David Hemous (2010). "The Environment and Directed Technical Changes", NBER Working Paper 15451, http://www.nber.org/papers/w15451

Anderegg, William, James Prall, Jacob Harold og Stephen Schneider (2010). "Expert Credibility in Climate Change", Proceedings of the National Academy of Science of the United States of America, Early online version: http://www.pnas.org/content/ early/2010/06/22/1003187107.full.pdf+html

Concito (2010a). Klimabarometeret, februar 2010.

http://www.concito.info/uploads/Klimabarometeretfebr2010.pdf

Concito (2010b). Klimabarometeret, juni 2010.

http://www.concito.info/upload/udgivelser_7_1286164835.pdf

Concito (2010c). Klimabarometeret, oktober 2010.

http://www.concito.info/upload/udgivelser_13_3649478455.pdf

EU (2009). Europeans' attitudes towards climate change, Special Eurobarometer 300. http://ec.europa.eu/public_opinion/archives/ebs/ebs_300_full_en.pdf

FN (2010). COP15/CMP5: Analysis of the Process, Outcomes and Implications. http:// www.unep.org/ROA/amcen/docs/AMCEN_Events/climate-change/COP15_Analysis.pdf

Franck, Travis (2008). "A Behavioral Model of Hurricane Risk and Coastal Adaptation", Conference Proceedings, The 2008 International Conference of the System Dynamics Society, Athens, Greece. http://www.systemdynamics.org/conferences/2008/proceed/papers/FRANC361.pdf'

Gallop-Norge (2010). The TNSGallup ClimateBarometer 1/2010, Daniel Rees, Project Manager, TNSGallup: http://www.cicero.uio.no/about/klimaforum/230610_ Rees.pdf

Gallup-USA (2009). Awareness, Opinions About Global Warming Vary Worldwide. http://www.gallup.com/poll/126560/americans-global-warming-concerns-continue-drop.aspx 
Gallup-USA (2010). Americans' Global Warming Concerns Continues to Drop. http:// www.gallup.com/poll/126560/americans-global-warming-concerns-continuedrop.aspx

Hinchliffe, S. (1996). "Helping the Earth Begins at Home", Global Environmental Change, 6. årg., pp. 53-62.

IEA (2010). International Energy Agency (IEA): Responding to Climate Change: A Brief Comment on International Emissions Reduction Pledges. http://www.iea.org/journalists/docs/pledges.pdf

Information (2010). informations netavis: http://www.information.dk/222092 (29. november, 2010).

Ipsos MORI poll (2010). World Questions: http://www.kcl.ac.uk/kingsanswers/news/ records/pollingresults.aspx

IPCC (2007) Summary for policymakers. Climate Change 2007: The Physical Science Basis. Contribution of Working Group I to the Fourth Assessment Report of the Intergovernmental Panel on Climate Change (IPCC), S. Solomon et al. (red.), Cambridge: Cambridge University Press.

Kahneman, Daniel og Amos Tversky (1979). "Prospect Theory: An Analysis of Decisions Under Risk", Econometrica, 47. årg., nr. 2, pp. 263-291.

Keller, Carmen, Michael Siegrist og Heinz Gutscher (2006). "The Role of the Affect and Availability Heuristics in Risk Communication", Risk, Analysis, 26. årg., pp. 631-639.

Leiserowitz Anthony, Edward Maibach og Connie Roser-Renouf (2010). Clobal Warming's Six Americas (January 2010). New Haven: Yale University and George Mason University. Yale Project on Climate Change. http://environment.yale.edu/uploads/ SixAmericasJan2010.pdf

I indley, D.V. (1985). Making Decisions, John Wiley \& Sons; 2nd rev. ed.

Lorenzoni, Irene, Anthony Leiserowitz, Miguel Doria, Wouter Poortinga og Nick Pidgeon (2006). "Cross-National Comparisons of Image Associations with 'Global Warming' and 'Climate Change' among Laypeople in the United States of America and Great Britain”, Journal of Risk Research, 9. årg, nr. 3, pp. 265-281.

Lowc, Thomas (2006). "Vicarious Experience vs. Scientific Information in Climate Change Risk Perception and Behaviour: a Case Study of Undergraduate Students in Norwich, UK", Teibnical Report 43, Tyndall Centre for Climate Change Research. Macnaghten, Phil og Michael Jacobs (1997). "Public Identification with Sustainable Development: Investigating Cultural Barriers to Participation", Global Environmental Change, 7. årg., nr. 1, pp. 5-24.

Mandag Morgen (2010). Nr. 1015 marts, http: http://www.mandagmorgen.no/halvenorge-mener-klimatrusselen-er-overdrevet (25. oktober, 2010) 
Moser, Susanne C. og Lisa Dilling (2004). "Making Climate Hot: Communicating the Urgency and Challenge of Global Climate Change", Environment, 46. årg., nr. 10 , pp. 32-46.

O'Neill, Saffron og Sophie A. Nicholson-Cole (2009). "Fear Won't Do It: Promoting Positive Engagement with Climate Change Through Visual and Iconic Representations", Science Communication, 30. årg., pp. 355-379.

Pew Research Center (2009). Public Praises Science; Scientists Fault Public: Section 5: Evolution, Climate Change and Other Issues, Washington, DC: Pew Research Center. http://people-press.org/reports/pdf/528.pdf

Rothman, Alexander J. og Peter Salovey (1997). "Shaping Perceptions to Motivate Healthy Behavior: The Role of Message Framing", Psychological Bulletin, 121. årg., pp. 3-19.

Ropeik, David (2010). How Risky Is It, Really? Why Our Fears Don't Always Match the Facts, McGraw-Hill.

Sandler, Todd (1997). Global Challenges, An Approach to Environmental, Political and Economic Problems, Cambridge: Cambridge University Press.

Slovic Paul, Baruch Fischhoff og Sarah Lichtenstein (1982). "Why Study Risk Perception?", Risk Analysis, 2. årg., pp. 83-93.

Slovic, Paul og Elke U. Weber (2002). "Perception of Risk Posed by Extreme Events", paper for Risk Management Strategies in an Uncertain World, Palisades, New York.

Spence, Alexa og Nick F. Pidgeon (2009). "Psychology, Climate Change and Sustainable Behaviour", Environment, 51. årg., pp. 8-18.

Spence, Alexa, Wouter Poortinga, Catherine Butler og Nick F. Pidgeon (2011). "Perception of Climate Change and Willingness to Save Energy Related to Flood Experience", Nature Climate Change, 1. årg., pp. 1-4.

Stern, Nicholas (2006). Stern Review on the Economics of Climate Change, Cambridge: Cambridge University Press.

Sunstein, Cass R. (2007). "Essay on the Divergent American Reaction to Terrorism and Climate Change", Columbia Law Review, 107. årg., 503-558.

Weber, Elke U. (2010). "What Shapes Perceptions of Climate Change?", Wiley Interdisciplinary Revieus: Climate Change, 1. årg., pp. 332-342.

Whitmarsh, Lorraine (2008). "Are Flood Victims More Concerned about Climate Change Than Other People? The Role of Direct Experience in Risk Perception and Behavioural Response", Journal of Risk Research, 11. årg., nr. 3, 351-374.

WHO (2009). Risk Communication, http://www.who.int/foodsafety/micro/riskcommunication/en/

WMO (2010). Press Release No. 903, http://www.wmo.int/pages/mediacentre/press_ releases/pr_903_en.html 